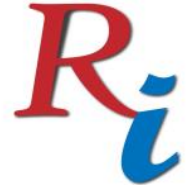

Asia Proceedings of Social Sciences

(APSS)

www.readersinsight.net/APSS

\title{
IMPACT OF TRADE LIBERALIZATION ON ECONOMIC DEVELOPMENT IN NIGERIA BASED ON ARDL APPROACH \\ Sunday Elijah*
}

Department of Economics, Federal University Gusau,

Zamfara State,

Nigeria.

Department of Economics,Faculty of Economics and Management,

Universiti Putra Malaysia.

Malaysia

\section{Ahmed Balarabe Musa}

Department of General Studies

Nuhu Bamalli Polytechnic, Zaria,

Nigeria

Department of Economics, Faculty of Economics and Management, Universiti Putra Malaysia.

Malaysia

*Corrosponding author's Email: elijahsundayecons@ gmail.com

Peer-review under responsibility of $3^{\text {rd }}$ Asia International Multidisciplanry Conference 2019 editorial board

(http://www.utm.my/asia/our-team/)

(C) 2019 Published by Readers Insight Publisher, lat 306 Savoy Residencia, Block 3 F11/1,44000 Islamabad. Pakistan,

info@readersinsight.net

This is an open access article under the CC BY-NC-ND license (http://creativecommons.org/licenses/by-nc-nd/4.0/). 


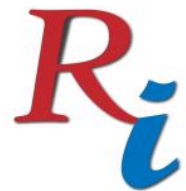

Asia Proceedings of Social Sciences

(APSS)

www.readersinsight.net/APSS

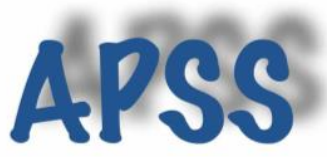

\section{Rese a r ch H igh I ight s}

This research examined trade liberalization as one of the drivers of economic development between 1986 - 2016, according to World Development Report, irrespective of under unfavourable or favourable environment, open economies perform better compared with closed economy. It is acceptable standard that trade liberalization brings about employment generation, income creation, resource production, large total output improvements and relaxation or removal of foreign trade limitations (Nnadozie, 2013). Empirical researches was done in Nigeria on relationships between trade and economic development (Ehinomen \& Da'silva, 2014)(Ezeuchenne, 2017) they had varied findings because of poor coverage, different techniques and sample size, therefore the need for empirical investigation; the period of choice was because of data availability. Autoregressive Distributed Lag(ARDL) was used as research econometric tool. The study findings revealed that trade liberalization did not cause growth during the period of the study.

\section{Research Objectives}

Developing economies of Sub-Saharan African countries and Nigeria is particular is faced with problem of growth among other challenges. The debate of economic growth key drivers had been and still on (Lewis, 1954)(Barro \& Sala-i-Martin, 2004). These scenario by extension include economic openness and stable exchange rate etc. Nigeria's performance economically was discouraging and confusing, economic data showed insignificant and confusing welfare advancement of Nigeria's populace. Growth rate annually averagely 7 percent showing Nigeria is fast growing economy among the economies of the world, the growth was mainly brought by trade and agriculture. The indicators of social welfare improvement was slower than expected. The reduction of poverty and opportunities of employment is not in pace with population growth indicating that social distress to Nigerians are increasing mostly to youth. Slowly in accomplishment of Sustainable Development Goals compared to other countries, Nigeria's economy has remained redundant since crude oil was discovered.

Trade liberalization \& openness, economic growth \& development is and have been topics in literature in different countries (Ehinomen \& Da'silva, 2014), the study found significant and positive relationship while Kingsley (2014) got significant negative relationship, hence, there is need to study it.

\section{Methodology}

This study used ARDL as research econometric tool for the estimate to answer the questions of the study objectives. The variables were tested and stationarity level known. Annual data from Central Bank of Nigeria statistical bulletin was used, little modification was done to the model by Onoh (2013) and adopted. For the connection estimate between investigation variables, ARDL developed by Pesaran et al. (2001) was used. It gives avenue for variables of mixed stationarity, so that it can be used in a model even if they are integrated at $I(0)$ or $I(1)$, it gives room for robust and reliable results whether the observations are small or large. Finally, it gives a long-run unbiased result, even if some of the regressors are endogenous and it still gives valid f-statistics.

\section{Results}

The ADF at first difference confirmed that the variables [real gross domestic product (RGDP), import (IMP), openness (OPEN) and export (EXPORT)] are stationary. The average rates 


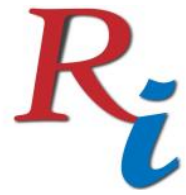

\section{Asia Proceedings of Social Sciences \\ (APSS) \\ www.readersinsight.net/APSS}

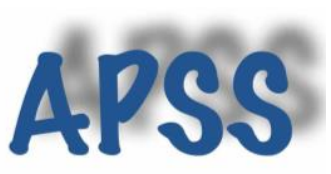

(mean) of openness, real GDP, import and export are all positive. The variables short-run impact on dependent variables of export and import had significant and positive impact on economic growth. A percent of increase in export and import could lead to $15 \%$ and $20 \%$ increase in economic growth respectively. The coefficient of error correction model showed a correct sign and statistically significant, it measure dependent variables speed of adjustment at which equilibrium is achieved, the results confirmed that $52 \%$ of any disequilibrium in economic growth can be adjusted within a lag (a year). The impact of long-run revealed that export and imports both had positive and significant impact on economic growth in the longrun at $1 \%$ level of significance. Diagnostic test was conducted to check the reliability of results, according to the result, the finding are correct because it passed all major tests in normality forms, serial correlation, heteroscedasticity and function form. The CUSUM and CUSUMQ revealed the estimated model is stable.

\section{Findings}

The study revealed that economic openness did not cause economic growth within the study period. The impact of long-run revealed that export and imports both had positive and significant impact on economic growth in the long-run. The coefficient of error correction model showed a correct sign and statistically significant, it measure dependent variables speed of adjustment at which equilibrium is achieved, the results confirmed that $52 \%$ of any disequilibrium in economic growth can be adjusted within a lag, therefore there is need for the Nigerian to diversify her economy to achieve growth led by export.

\section{References}

Barro, R. J., \& Sala-i-Martin, X. (2004). Economic growth second edition: Cambridge MA.: The MIT Press.

Ehinomen, C., \& Da'silva, D. (2014). Impact of trade openness on the output growth in the Nigerian economy. British Journal of Economics, Management \& Trade, 4(5), 755-768.

Ezeuchenne, K. (2017). International Trade and Economic Growth in Nigeria. IOSR Journal of Humanities and Social Science, 22(6), 33 - 43.

Kingsley, O. K. (2014). Is trade openness valid for Nigeria's long-run growth? A co-integration Approach? Journal of African Institute for Applied Economics.

Lewis, W. A. (1954). Economic development with unlimited supplies of labour. The manchester school, 22(2), $139-191$.

Nnadozie, E. (2013). Does trade cause growth in Nigeria. Journal of African Development, 6(1), 52-75.

Pesaran, M. H., Shin, Y., \& Smith, R. J. (2001). Bounds testing approaches to the analysis of level relationships. Journal of applied econometrics, 16(3), 289-326.

Ugochukwu, U., Amah, O., \& Onoh, J. O. (2013). The impact of foreign direct investment on the Nigerian economy. European Journal of Business and Management, 5(2), 2222-1905. 